\title{
Chronotype and Sleep Quality in Patients with Inflammatory Bowel Disease
}

\author{
Enflamatuvar Barsak Hastalıkları olan Hastalarda Kronotip ve Uyku Kalitesi \\ • Elmas Biberci Keskin, • Çiğdem Dilek Şahbaz* \\ Bezmialem Vakif University, Department of Gastroenterology, Istanbul, Turkey \\ *Bezmialem Vakif University, Department of Psychiatry, Istanbul, Turkey
}

\section{Abstract}

\begin{abstract}
Aim: Chronotype and sleep disturbance are both considered risk factors for chronic autoimmune diseases. However, there is lack of knowledge with respect to chronic inflammatory bowel disease and chronotype patterns. Therefore, we investigated the chronotype and sleep quality in patients with ulcerative colitis and Crohn's disease.
\end{abstract}

Methods: Patients with Crohn's disease and ulcerative colitis were prospectively enrolled in the study. Chronotype and sleep quality were assessed using the Mornings Evenings Questionnaire and Pittsburg Sleep Quality Index scores and the results were compared to healthy controls.

Results: A total of 134 patients were included in the study. Of these patients 41 had Crohn's disease, 49 had ulcerative colitis and 44 were healthy controls. Eveningness was more common in patients with Crohn's disease and ulcerative colitis compared to controls $(12.2 \%, 18.4 \%, 0 \%$, respectively, $p<0.001)$. However, there was no difference in chronotype based on the disease activity or between Crohn's disease and ulcerative colitis. In terms of sleep quality, inflammatory bowel disease was found to be an independent risk factor for sleep disturbance $(O R=1.5$; 1.04-2.33 95\% Cl; $p=0.02$ ).

Conclusion: Eveningness was more common in patients with Crohn's disease and ulcerative colitis compared to controls. In addition, inflammatory bowel disease seems to be a significant risk factor for sleep disturbance.

Keywords: Chronotype, Crohn's disease, sleep disturbance, sleep quality, ulcerative colitis
Öz

Amaç: Kronotip ve uyku bozukluğu, kronik otoimmün hastalık gelişimi bir risk faktörü olarak kabul edilir. Öte yandan, kronotip çeşitlerinin enflamatuvar barsak hastalıkları üzerine olan etkisi yeterince bilinmemektedir. Bu nedenle ülseratif kolit ve Crohn hastalığı olan hastaların kronotip ve uyku kalitesini araştırdık.

Yöntemler: Crohn hastalığı ve ülseratif kolit tanısı olan hastalar prospektif olarak çalışmaya dahil edildi. Kronotip ve uyku kalitesini belirlemek için "Sabahçıl Akşamcı" ve "Pittsburg Uyku Kalitesi Endeksi" anketleri kullanıldı. Sonuçlar sağlıklı hastalarla karşılaştırıldı.

Bulgular: Çalışmaya 41'i Crohn hastalığı, 49'u ülseratif kolit ve 44'ü de sağlıklı kontrol olmak üzere toplam 134 hasta alındı. Crohn hastalığı ve ülseratif koliti olan hastalarda akşamcıl kronotip kontrol grubuna göre daha sık bulundu (sırasıyla \%12,2, $\% 18,4$, ve $\% 0$ p<0,001). Öte yandan Crohn ve ülseratif kolit hastalarında hastalık aktivitesi ile kronotip arasında fark yoktu. Uyku kalitesi açısından, enflamatuvar barsak hastalığı varlığının uyku bozukluğu için bağımsız bir risk faktörü olduğu bulundu (OR=1,5; 1,04-2,33\%95 Cl; $p=0,02$ ).

Sonuç: Crohn hastalığı ve ülseratif koliti olan hastalarda akşamcıl kronotip kontrol grubuna göre daha sık bulundu. Ayrıca enflamatuvar barsak hastalığı, uyku bozukluğu için önemli bir risk faktörü olarak gözükmektedir.

Anahtar Sözcükler: Kronotip, Crohn hastalığı, uyku bozukluğu, uyku kalitesi, ülseratif kolit
Address for Correspondence/Yazışma Adresi: Elmas Biberci Keskin, Bezmialem Vakif University, Department of Gastroenterology, İstanbul, Turkey Phone: +90 2124531700 E-mail: elmasbiberci@yahoo.com ORCID: orcid.org/0000-0002-5528-830X Received/Geliş Tarihi: 24 September 2019 Accepted/Kabul Tarihi: 24 November 2019

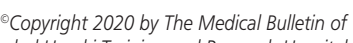
istanbul Haseki Training and Research Hospital The Medical Bulletin of Haseki published by Galenos Yayınevi. ${ }^{\circledR}$ Telif Hakkı 2020 istanbul Haseki Eğitim ve Araştırma Hastanesi Haseki Tıp Bülteni, Galenos Yayınevi tarafından yayınlanmıştır. 


\section{Introduction}

Chronotype refers to the individual differences in the time at which people prefer to do certain behaviors, particularly sleeping which is influenced by circadian rhythms, genetics and external factors (1). In chronobiology, chronotypes are generally classified as morning, intermediate and evening types. While morning type people tend to wake up in the early morning hours, evening type people tend to sleep later and wake up later. Each chronotype shows different psychological, behavioral and biological characteristics including temper, attentiveness, task performance, body temperature and, cortisol and melatonin release $(2,3)$.

All organisms have circadian rhythms which are controlled biologically. This balance is controlled by the molecular circadian clock found in almost all cells in the mammalian body (4). The molecular circadian clock is responsible for occurrence of the circadian rhythm, and is composed of transcriptional-translational cycles which are completed approximately in 24 hours. Many factors are involved in the quality of sleep, but the circadian rhythm has the greatest impact. The central circadian clock regulates melatonin production in the pineal gland and it is important in terms of the effects of circadian rhythm on sleep (5). Chronotype is a behavioral process which occurs as a result of interaction of the circadian rhythm with environmental factors.

Studies have shown that morning chronotype individuals have a healthier lifestyle, stronger internal control and higher self-confidence compared to evening chronotype individuals (6). Evening type individuals display irregular lifestyle characteristics in terms of eating, exercise, social affairs and daily activities (2). There is a correlation between lifestyle, sleep-awake cycle and sleep quality.

The two major inflammatory bowel diseases (IBDs), Crohn's disease (CD) and ulcerative colitis (UC), are inflammatory and heterogeneous diseases characterized by recurrent episodes and remissions $(7,8)$. The pathogenesis of these diseases is not fully understood. Genetic tendency, disrupted immune response and environmental factors including dietary habits and smoking which affect intestinal microbiota, are involved in the etiology. It is thought that depression and anxiety are also involved. In addition, gut-brain axis dysfunction is also thought to play a role in the development of IBD. Although evidence suggests that evening chronotype is associated with many chronic diseases, there is no sufficient evidence in terms of the role of chronotype in the development of gastrointestinal diseases. Therefore, we investigated the relationship of chronotype characteristics and sleep quality with IBSs and its effect on disease activation.

\section{Methods}

Patients aged between 18 and 75 years with chronic IBD (CD and UC), who presented to Bezmialem Vakif University, Department of Gastroenterology between May 2019 and September 2019, were included in our prospective, observational and cross-sectional study (coordinates: latitude $41^{\circ} 1^{\prime} \mathrm{N}$; longitude $28^{\circ} 56^{\prime} \mathrm{E}$ ). The diagnosis of CD and UC was made by a specialist gastroenterologist based on clinical, laboratory and colonoscopy findings. The degree of disease activity was also determined with the same methods. Agematched healthy individuals without any chronic disease were included in the control group. Pregnant women, individuals who did not have adequate mental capacity and who had uncertain diagnosis were excluded from the study. Demographic characteristics, medical history, lifestyle habits, and clinical findings were determined by face to face interviews and by examining patient files. The study protocol was approved by Bezmialem Foundation University Ethics Committee and conducted in accordance with the principles of the Declaration of Helsinki (approval no: 16/311, date: 03.09.2019). Informed consent was obtained from all patients.

The participants were asked several questions to determine sleep patterns and chronotypes. For this purpose, the Horne and Ostberg (3) Morningness/ Eveningness Questionnaire (MEQ) was used. This test is a widely accepted and commonly used questionnaire that has been translated to many languages and it evaluates chronotype and the phase preferences of individual behavior over a 24-hour day. Its Turkish version was used in our study. It contains 19 items which are scored on a 4-item Likert type scale. In assessment, sleep duration, appetite, exercise preferences, psychological and behavioral factors are considered. The total score ranges between 16 and 86; a score of $59-86$ is considered morning type, a score of 42-58 is considered intermediate type and a score of 16-41 is considered evening type.

The Pittsburgh Sleep Quality Index (PSQI) is used to evaluate sleep quality (9). PSQI is a 19-item questionnaire composed of nine questions designed to measure sleep quality over a one-month time interval. The PSQI questionnaire questions are scored between 1 and 4 and the total score ranges between 0 and 21 . The questionnaire components are composed of seven subgroups including subjective sleep quality, sleep latency, sleep duration, sleep efficiency, sleep disturbances, use of sleep medication and daytime dysfunction in the last month. A total PSQI score above 5 indicates poor sleep quality.

\section{Statistical Analysis}

The data were assessed using the SPSS for Windows version 22.0 (SPSS Inc., Chicago IL, ABD). The numerical 
data were expressed as mean ( \pm standard deviation) or median (interquartile range). The categorical variables were expressed as numbers and percentages. The distribution of the numerical data was examined using the Shapiro-Wilk test. The ANOVA or Kruskal-Wallis test was used to evaluate the numerical data between the groups and post-hoc analysis was conducted either using Tukey's method or the Mann-Whitney $U$ test where appropriate. Chi-square or Fisher's exact test was used to evaluate the categorical data. A two-sided $p$ value of less than 0.05 was considered statistically significant. Univariate and multivariate logistic regression analyses were performed to determine the variables which had an impact on sleep quality.

\section{Results}

A total of 134 subjects, 90 patients with chronic IBD and 44 controls, were included in the study. The mean age of the participants was $38.2 \pm 14.0$ years and female patients constituted the majority $(n=81,60.4 \%)$. Demographic characteristics and questionnaire scores (MEQ, PSQI and PSQI subgroups) of the groups are shown in Table 1. A statistically significant difference was found between the individuals who had IBD and the healthy controls in terms of body mass index $(C D=24.3 \pm 4.3, U C=22.6 \pm 4.4$, controls=27.8 $\pm 5.1, \quad \mathrm{p}<0.001)$. Patients with IBD had statistically significantly lower MEQ scores compared to healthy controls $(C D=51.73 \pm 7.69, U C=51.69 \pm 9.31$, Controls $=58.55 \pm 7.18, \mathrm{p}<0.001)$. In chronotype analysis, the intermediate type and evening type were found to be more common in patients with IBD than in control group, while the morning type was more common in the control group $(p<0.001)$. There was no significant difference in PSQI scores between the groups. Poor sleep quality was found with a higher rate in IBD patients compared to healthy controls, but the difference was not statistically significant (IBD 51\%, control=29\%, $p=0.061$ ). In PSQI subgroup analysis, a significant difference was found in terms of subjective sleep quality only between patients with $U C$ and controls $(U C=1.45 \pm 0.98$, controls $=0.95 \pm 0.86$,

\begin{tabular}{|c|c|c|c|c|c|}
\hline & $\begin{array}{l}\text { Crohn disease } \\
\mathrm{n}=41\end{array}$ & $\begin{array}{l}\text { Ulcerative colitis } \\
n=49\end{array}$ & $\begin{array}{l}\text { Healthy control } \\
\mathrm{n}=44\end{array}$ & p & Post hoc \\
\hline $\begin{array}{l}\text { Age (years) } \\
\text { Median (Q1-Q3) }\end{array}$ & $33.7(19-83)$ & $40(17-76)$ & $40.3(24-64)$ & 0.048 & - \\
\hline Gender (male), n (\%) & $18(43.9 \%)$ & $22(44.9 \%)$ & $13(29.5 \%)$ & 0.252 & - \\
\hline Smoker, n (\%) & $7(17.1)$ & $6(12.2)$ & *18 (40.9) & 0.030 & - \\
\hline Body mass index, $\left(\mathrm{kg} / \mathrm{m}^{2}\right)$ mean $(\mathrm{SD})$ & $24.3 \pm 4.3$ & $22.6 \pm 4.4$ & $27.8 \pm 5.1$ & $p<0.001$ & $\begin{array}{l}\text { UC-CD: } p=0.22 \\
\text { UC-HC: } p<0.001 \\
\text { CD-HC: } p=0.004\end{array}$ \\
\hline Comorbid diseases, $\mathrm{n}(\%)$ & $5(12.2 \%)$ & $11(22.4 \%)$ & $0(\%)$ & 0.004 & - \\
\hline MEQ score, mean (SD) & $51.73 \pm 7.69$ & $51.69 \pm 9.31$ & $58.55 \pm 7.18$ & $p<0.001$ & $\begin{array}{l}\text { UC-CD: } p=1 \\
\text { UC-HC: } p=0.001 \\
\text { CD-HC: } p<0.001\end{array}$ \\
\hline \multicolumn{6}{|l|}{ Chronotypes, mean (SD) } \\
\hline Morningness & $7(17.1 \%)$ & $14(28.6 \%)$ & $24(54.5 \%)$ & \multirow{3}{*}{$p<0.001$} & \multirow{3}{*}{-} \\
\hline Intermediate & $29(70.7 \%)$ & $26(53.1 \%)$ & $20(45.5 \%)$ & & \\
\hline Eveningness & $5(12.2 \%)$ & $9(18.4 \%)$ & 0 & & \\
\hline PSQ index, median (Q1-Q3) & $6(1-14)$ & $6(0-19)$ & $4(1-14)$ & 0.176 & - \\
\hline PSQ >6, n (\%) & $21(51.2 \%)$ & $25(51 \%)$ & $13(29.5)$ & 0.061 & - \\
\hline Subjective sleep quality, mean (SD) & $1.41 \pm 0.86$ & $1.45 \pm 0.98$ & $0.95 \pm 0.86$ & 0.011 & $\begin{array}{l}\text { UC-CD:0.918 } \\
\text { UC-HC: } 0.010 \\
\text { CD-HC: } 0.080\end{array}$ \\
\hline Sleep latency, mean (SD) & $1.12 \pm 1.02$ & $1.31 \pm 1.04$ & $1.05 \pm 1.01$ & 0.419 & - \\
\hline Sleep duration, mean (SD) & $0.63 \pm 0.88$ & $0.86 \pm 1.06$ & $0.48 \pm 0.69$ & 0.293 & - \\
\hline $\begin{array}{l}\text { Habitual sleep efficiency, } \\
\text { mean (SD) }\end{array}$ & $0.37 \pm 0.79$ & $0.65 \pm 1.09$ & $0.30 \pm 0.70$ & 0.312 & - \\
\hline Sleep disturbances, mean (SD) & $1.29 \pm 0.64$ & $1.29 \pm 0.89$ & $1.20 \pm 0.63$ & 0.883 & - \\
\hline Use of sleeping medicine, mean (SD) & $0.27 \pm 0.73$ & $0.16 \pm 0.65$ & $0.05 \pm 0.21$ & 0.363 & - \\
\hline Daytime dysfunction, mean (SD) & $0.93 \pm 1.43$ & $0.76 \pm 1.03$ & $0.64 \pm 0.83$ & 0.903 & - \\
\hline
\end{tabular}


$p=0.01$ ). There was no statistically significant difference in the other PSQI subgroups. Logistic regression analysis showed that presence of IBD was an independent risk factor for development of sleep disorder [Odds ratio $(O R)=1.56,1.04-2.33$ confidence interval $(C l)=95 \%$, $\mathrm{p}=0.02$, Table 2]. When patients with active disease were compared to those with remission, there was no statistically significant difference with respect to MEQ and PSQI scores (Table 3).

\section{Discussion}

In our study, we found that chronotypes were markedly different between patients who had IBD and healthy individuals. The intermediate type and evening type were found to be more common in IBD group, while the morning type was found with a higher rate in the healthy controls. A significant difference could not be found between UC and CD in terms of chronotype and disease exacerbation. In addition, logistic regression analysis showed that IBDs was an independent risk factor for poor sleep quality $(\mathrm{OR}=1.5)$. The circadian rhythm regulated by a complex mechanism including mainly the central nervous system, has a great importance in maintaining homeostasis in the body. Disruption of the circadian rhythm suppresses melatonin production. Thus, disruption of the circadian rhythm may lead to sleep disorders and alternatively, sleep disorders may also affect the circadian rhythm. In other words, the relationship between sleep and the circadian rhythm is interwoven and their relative actions on each other are not fully known.

Sleep has many effects also on the immune system. It is known that it regulates humoral and cellular immunity. It was shown to affect cellular immunity by way of changes especially in the number of helper T cells (10). Sleep deprivation increases the levels of interleukin-1, tumor necrosis factor- $\alpha$ and interferon. An everincreasing body of evidence suggests that inflammatory cytokines have both direct and indirect effects on

\begin{tabular}{|c|c|c|c|}
\hline & Active $(n=44)$ & Remission $(n=46)$ & p \\
\hline Ulcerative colitis (n, \%) & $26(59.1 \%)$ & $23(50.0 \%)$ & \multirow[t]{2}{*}{0.387} \\
\hline Chron's disease $(n, \%)$ & $18(40.9 \%)$ & $23(50.0 \%)$ & \\
\hline Age (years), median (Q1-Q3) & $33(17-66)$ & $37(18-63)$ & 0.230 \\
\hline \multicolumn{4}{|l|}{ Gender (n, \%) } \\
\hline Female & $24(54.5 \%)$ & $26(45.5 \%)$ & \multirow[t]{2}{*}{0.850} \\
\hline Male & $20(56.5 \%)$ & $20(43.5 \%)$ & \\
\hline Disease duration (months), median (min-max) & $24(2-144)$ & $48(3-240)$ & 0.011 \\
\hline Body mass index $\left(\mathrm{kg} / \mathrm{m}^{2}\right)$, median (Q1-Q3) & $22.9(15.2-33.3)$ & $23.0(16.6-35.6)$ & 0.70 \\
\hline Smoker (n, \%) & $4(9.1 \%)$ & $9(19.6 \%)$ & 0.381 \\
\hline \multicolumn{3}{|l|}{$\operatorname{MEQ}(n, \%)$} & \multirow{4}{*}{0.657} \\
\hline Morningness & $12(27.3 \%)$ & $9(19.6 \%)$ & \\
\hline Intermediate & $25(56.8 \%)$ & $30(65.2 \%)$ & \\
\hline Eveningness & $7(15.9 \%)$ & $7(15.2 \%)$ & \\
\hline PSQ index, median (Q1-Q3) & $6(1-18)$ & $5(1-19)$ & 0.339 \\
\hline PSQI >6 (n, \%) & $24(54.5 \%)$ & $21(45.7 \%)$ & 0.399 \\
\hline Subjective sleep quality, mean (SD) & $1.55 \pm 0.84$ & $1.33 \pm 0.99$ & 0.191 \\
\hline Sleep latency, mean (SD) & $1.20 \pm 1.02$ & $1.24 \pm 0.05$ & 0.920 \\
\hline Sleep duration, mean (SD) & $0.75 \pm 1.01$ & $0.76 \pm 0.97$ & 0.938 \\
\hline Habitual sleep efficiency, mean (SD) & $0.48 \pm 0.92$ & $0.57 \pm 1.02$ & 0.701 \\
\hline Sleep disturbances, mean (SD) & $1.52 \pm 0.73$ & $1.07 \pm 0.77$ & 0.062 \\
\hline Use of sleeping medicine, mean (SD) & $0.18 \pm 0.69$ & $0.22 \pm 0.69$ & 0.534 \\
\hline Daytime dysfunction, mean (SD) & $0.91 \pm 1.09$ & $0.76 \pm 1.35$ & 0.257 \\
\hline White blood cell $\left(\times 10^{3}\right)$, median (Q1-Q3) & $8.76(1.9-17.2)$ & $7.27(3.8-14.4)$ & 0.089 \\
\hline Hemoglobin, mean (SD) & $12.3(2.1)$ & $12.9(1.7)$ & 0.12 \\
\hline C-reactive protein (mg/dL), median (Q1-Q3) & $10.1(0.2-229.1)$ & $2.9(0.2-263.1)$ & 0.032 \\
\hline
\end{tabular}




\begin{tabular}{|c|c|c|c|c|}
\hline & \multirow[t]{2}{*}{$p$} & \multirow[t]{2}{*}{ OR } & \multicolumn{2}{|l|}{$95 \% \mathrm{Cl}$} \\
\hline & & & Lower & Upper \\
\hline Inflammatory bowel disease & 0.02 & 1.56 & 1.04 & 2.33 \\
\hline Smoking & 0.29 & 1.65 & 0.64 & 4.26 \\
\hline Age & 0.86 & 0.99 & 0.97 & 1.02 \\
\hline Body mass index & 0.92 & 0.99 & 0.91 & 1.08 \\
\hline \multicolumn{5}{|l|}{ Cl: Confidence interval. OR: Odds ratio } \\
\hline
\end{tabular}

sleep (11). The role of sleep disorders in patients with IBD has been examined in a small number of studies. For example, Ananthakrishnan et al. (12) showed that sleeping for less than 6 hours and more than 9 hours daily increased the risk for UC, but there was no such correlation with CD in their NHS I and NHSII studies which included women only (13).

In terms of intestinal diseases, the circadian rhythm has many effects on cell proliferation, intestinal motility and immunity in the intestines. Disruption of the circadian rhythm leads to damage in the intestinal barrier, negative changes in the intestinal microbiota and as a result, to intestinal inflammation (14). All these factors support the pathogenesis of IBD. Thus, disruption of the circadian rhythm and poor sleep quality may affect both the function of the gastrointestinal system and lead to gastrointestinal disorders (15). There are many publications that show the relationship between circadian rhythm and IBD. Sobolewska-Wlodarczyk et al. (16) examined the effect of poor sleep quality on IBD and its relationship with disease exacerbation. They found that poor sleep quality was associated with IBD exacerbations. Chrobak et al. (14) showed that evening chronotype was observed with a higher rate in patients with CD compared to healthy controls. In other studies, it was shown that disease course could be more aggressive in patients with IBD who had evening chronotype (17). In our study, the intermediate and evening types were found to be more common in patients with IBD.

On the other hand, the disease itself or treatments may cause a vicious cycle by triggering sleep disorders. Ranjbaran et al. (18) reported that night diarrhea and abdominal pain symptoms could severely disrupt sleep quality in IBD. Sleep disorders may also occur as a result of side effects of the drugs used in the treatment of IBD exacerbation including steroids, mesalazine and aminosalicylic acid. Thus, treatment of gastrointestinal inflammation by using corticosteroid-sparing agents including especially immunomodulators or biological substances may increase sleep quality (19).

\section{Study Limitations}

This was a single-center study with a relatively small sample size. In addition, there was a no follow-up to investigate the disease flare-up with respect to chronotype.

\section{Conclusion}

The chronotype of patients with IBD is significantly different from the controls. Evening type chronotype is more common in IBD patients than in controls who show mainly morning chronotypes. However, there was no difference in chronotypes between patients with UC and CD. Furthermore, the chronotypes did not differ according to disease activity of IBD. Finally, IBD was found to be a significant risk factor for sleep disturbance.

\section{Authorship Contributions}

Concept: E.B.K., Ç.D.Ş. Design: E.B.K., Ç.D.Ş. Data Collection or Processing: E.B.K., Ç.D.Ş. Analysis or Interpretation: E.B.K., Ç.D.Ş. Literature Search: E.B.K., Ç.D.S. Writing: E.B.K.

Conflict of Interest: No conflict of interest was declared by the authors.

Financial Disclosure: The authors declared that this study received no financial support.

\section{References}

1. Borisenkov MF, Perminova E V, Kosova AL. Chronotype, sleep length, and school achievement of 11- to 23-year-old students in northern European Russia. Chronobiol Int 2010;27:1259-70.

2. Muller MJ, Haag A. The concept of chronotypes and its clinical importance for depressive disorders. Int J Psychiatry Med 2018;53:224-40.

3. Horne JA, Ostberg O. A self-assessment questionnaire to determine morningness-eveningness in human circadian rhythms. Int J Chronobiol 1976;4:97-110.

4. Codoner-Franch P, Gombert M. Circadian rhythms in the pathogenesis of gastrointestinal diseases. World J Gastroenterol 2018;24:4297-303.

5. Slominski RM, Reiter RJ, Schlabritz-Loutsevitch N, Ostrom RS, Slominski AT. Melatonin membrane receptors in peripheral tissues: distribution and functions. Mol Cell Endocrinol 2012;351:152-66.

6. Chelminski I, Ferraro FR, Petros T V, Plaud JJ. An analysis of the "eveningness-morningness" dimension in "depressive" college students. J Affect Disord 1999;52:19-29.

7. Ribaldone DG. ACG Clinical Guideline on Crohn's Disease: A Point of View from Europe. Am J Gastroenterol 2019;114:826.

8. Rubin DT, Ananthakrishnan AN, Siegel CA, Sauer BG, Long MD. ACG Clinical Guideline: Ulcerative Colitis in Adults. Am J Gastroenterol 2019;114:384-413.

9. Buysse DJ, Reynolds CF 3rd, Monk TH, Berman SR, Kupfer DJ. The Pittsburgh Sleep Quality Index: a new instrument for 
psychiatric practice and research. Psychiatry Res 1989;28:193213.

10. Dimitrov S, Lange $T$, Tieken S, Fehm HL, Born J. Sleep associated regulation of $T$ helper $1 / T$ helper 2 cytokine balance in humans. Brain Behav Immun 2004;18:341-8.

11. Kawada T. Elevated plasma total tau and interleukin-6 concentrations in patients with obstructive sleep apnea with special reference to neuronal damage. Sleep Med 2019;59:123.

12. Ananthakrishnan AN, Khalili H, Pan A, et al. Association between depressive symptoms and incidence of Crohn's disease and ulcerative colitis: results from the Nurses' Health Study. Clin Gastroenterol Hepatol 2013;11:57-62.

13. Ananthakrishnan AN, Khalili H, Konijeti GG, et al. Sleep duration affects risk for ulcerative colitis: a prospective cohort study. Clin Gastroenterol Hepatol 2014;12:1879-86.

14. Chrobak AA, Nowakowski J, Zwolinska-Wcislo M, et al. Associations between chronotype, sleep disturbances and seasonality with fatigue and inflammatory bowel disease symptoms. Chronobiol Int 2018;35:1142-52.
15. Voigt RM, Forsyth $C B$, Keshavarzian A. Circadian rhythms: a regulator of gastrointestinal health and dysfunction. Expert Rev Gastroenterol Hepatol 2019;13:411-24.

16. Sobolewska-Wlodarczyk A, Wlodarczyk M, Banasik J, Gasiorowska A, Wisniewska-Jarosinska M, Fichna J. Sleep disturbance and disease activity in adult patients with inflammatory bowel diseases. J Physiol Pharmacol 2018;69.

17. Qazi T, Farraye FA. Sleep and Inflammatory Bowel Disease: An Important Bi-Directional Relationship. Inflamm Bowel Dis 2019;25:843-52.

18. Ranjbaran Z, Keefer L, Farhadi A, Stepanski E, Sedghi S, Keshavarzian A. Impact of sleep disturbances in inflammatory bowel disease. J Gastroenterol Hepatol 2007;22:1748-53.

19. Stevens BW, Borren NZ, Velonias G, et al. Vedolizumab Therapy Is Associated with an Improvement in Sleep Quality and Mood in Inflammatory Bowel Diseases. Dig Dis Sci 2017;62:197-206. 